Jurnal Keperawatan Silampari

Volume 5, Nomor 1, Desember 2021

e-ISSN: 2581-1975

p-ISSN: 2597-7482

DOI: https://doi.org/10.31539/jks.v5i1.3166

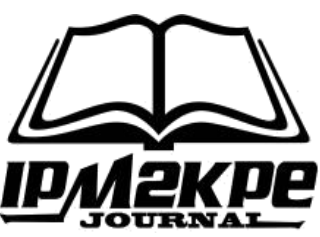

\title{
IMPLEMENTASI KEBIJAKAN PELAYANAN ANTENATAL CARE (ANC) BAGI IBU HAMIL PADA MASA PANDEMI COVID-19
}

\author{
Erika Pebriyanti ${ }^{1}$, Yuanita Windusari ${ }^{2}$, Haerawati Idris ${ }^{3}$ \\ Universitas Sriwijaya ${ }^{1,2,3}$ \\ ywindusari@unsri.ac.id ${ }^{2}$
}

\begin{abstract}
ABSTRAK
Penelitian ini bertujuan untuk menganalisis implementasi kebijakan pelayanan antenatal care bagi ibu hamil pada masa pandemi COVID-19 di Kabupaten Kepahiang dengan menggunakan teori Edward III. Metode penelitian ini menggunakan rancangan deskriptif kualitatif. Hasil penelitian menunjukkan bahwa komunikasi antara pihak tenaga kesehatan dengan ibu hamil, suami atau keluarga dalam pelaksanaan kegiatan antenatal care pada ibu hamil terjalin cukup lancar, sumber daya manusia dari tenaga kesehatan pelaksana kegiatan antenatal care telah tersedia sesuai kebutuhan, disposisi dan struktur birokrasi pada implementasi layanan antenatal care bagi ibu hamil pada masa pandemi COVID-19 di Kabupaten Kepahiang berjalan dengan baik. Simpulan, secara garis besar implementasi kebijakan pelayanan antenatal care bagi ibu hamil pada masa pandemi COVID-19 di Kabupaten Kepahiang berjalan dengan baik.
\end{abstract}

Kata Kunci: ANC, COVID-19, Ibu Hamil, Kebijakan

\begin{abstract}
This study aims to analyze the implementation of antenatal care service policies for pregnant women during the COVID-19 pandemic in Kepahiang Regency using Edward III's theory. This research method uses a qualitative descriptive design. The results showed that communication between health workers and pregnant women, husbands, or families in implementing antenatal care activities for pregnant women was relatively smooth. Human resources from health workers implementing antenatal care activities were available according to needs, disposition, and bureaucratic structure in service implementation. During the COVID-19 pandemic in Kepahiang Regency, antenatal care for pregnant women went well. In conclusion, in general, the performance of antenatal care service policies for pregnant women during the COVID-19 pandemic in the Kepahiang Regency went well.
\end{abstract}

Keywords: ANC, COVID-19, Pregnant Women, Policy

\section{PENDAHULUAN}

Saat ini pandemi COVID-19 sedang menguji ketahanan sistem pelayanan kesehatan diseluruh dunia termasuk Indonesia. Kemampuan dalam merespons secara cepat dan tepat menjadi kunci agar kita dapat melalui krisis ini dengan baik (Hasugian et al., 2021). Ibu hamil merupakan salah satu kelompok rentan terhadap risiko terinfeksi COVID-19 dikarenakan pada masa kehamilan ini terjadinya perubahan fisiologi yang mengakibatkan penurunan kekebalan parsial dan dapat menyebabkan dampak yang 
serius bagi ibu hamil itu sendiri (Aritonang, 2020). Dimasa pandemi Pemeriksaan kehamilan tentu akan mengalami kendala, akan tetapi dapat dilakukan selama ibu hamil dan petugas kesehatan menerapkan protokol kesehatan COVID-19 selama asuhan pemeriksaan kehamilan (Pitale, 2020). Oleh karena itu, di masa pandemi ini, ibu hamil perlu mengetahui cara melindungi diri dengan benar.

Keadaan akan semakin diperparah jika ibu hami masih berada pada usia muda yakni hamil di usia kurang dari 20 tahun. Begitu banyak bahaya yang mungkin akan timbul dikarenakan wanita yang hamil diusia kurang dari 20 tahun masih berada dalam masa pertumbuhan sehingga antara janin dan ibunya sendiri dapat terjadi kompetisi makanan, hal tersebut bisa memicu terjadinya Kekurangan Energi Kronik (KEK), anemia, kelahiran prematur serta prematur. Untuk mencegah hal tersebut kunjungan ANC harus dilakukan secara rutin guna mendeteksi sedari dini kelainan dimasa kehamilan yang dapat berbahaya bagi kesehatan serta keselamatan ibu dan janin dalam kandungannya (Unicef, 2019).

Pelaksanaan Usaha Kesehatan Masyarakat (UKM) yang direncanakan harus diperiksa untuk melihat apakah masih dapat dilaksanakan seperti biasa, apakah dapat dilakukan dengan metode atau teknologi lain, apakah dapat ditunda atau tidak dilaksanakan sama sekali, dan tentunya juga harus diperhatikan pencegahan dan pengendalian aturan infeksi (PPI) dan jarak fisik untuk memutus mata rantai penularan dan mengupayakan kesehatan ibu dan anak (Kementerian Kesehatan RI, 2020). Untuk itu diperlukan sebuh kebijakan yang dapat menjadi panduan bagi tenaga kesehatan dalam memberikan layanan kepada masyarakat.

Pemerintah melalui Kementerian Kesehatan membuat sebuah kebijakan berupa petunjukan praktis layanan kesehatan ibu dan bayi baru lahir selama Pandemi COVID19 nomor B-4 yang di terbitkan 5 April 2020. Sebagai upaya penurunan angka kematian ibu dan bayi, untuk mendukung Pemerintah Indonesia dalam memastikan kelanjutan pelayanan kesehatan Ibu dan Bayi Baru Lahir maka protokol ini disiapkan agar pelayanan tetap terlaksana selama wabah pandemi COVID-19. Protokol kesehatan disusun mengacu pada referensi yang dikeluarkan oleh Kementerian Kesehatan dan Organisasi Profesi, seperti: Pedoman Bagi Ibu Hamil, Ibu Nifas dan Bayi Baru Lahir selama pandemi COVID-19 (Gugus Tugas Percepatan Penanganan COVID-19, 2020).

Dijelaskan bahwa Pemerintah Daerah berkewajiban untuk memastikan kesiapan fasilitas kesehatan dalam protokoler tersebut dalam memberikan layanan kesehatan ibu dan anak dengan atau tanpa status terinfeksi COVID-19 di pelayanan kesehatan tingkat pertama (Puskesmas, Bidan Praktik Mandiri) dan fasilitas kesehatan rujukan (RS Rujukan COVID-19, RS mampu PONEK, RSIA). Dengan menggunakan teknologi informasi yang mudah diakses oleh ibu kegiatan konsultasi dimaksimalkan. Untuk layanan kesehatan ibu dan anak telemedicine perlu untuk disosialisasikan, Call center 119 ext 9 atau hotline yang disediakan khusus. Pasien terpisah dari Gedung Utama Puskesmas sehingga pasien KIA tidak bercampur dengan Pasien Umum serta prosedur lainnya. Puskesmas direkomendasikan untuk mengatur ulang fasilitas layanan KIA agar terpisah dengan Gedung Utama Puskesmas sehingga Pasien KIA tidak bercampur dengan Pasien Umum serta prosedur lainnya (Gugus Tugas Percepatan Penanganan COVID-19, 2020).

Data dari Dinas Kesehatan Kabupaten Kepahiang menunjukan bahwa aktivitas pelayanan ANC di Kabupaten Kepahiang belum menunjukkan hasil yang maksimal sejak masa pandemi COVID-19. Sampai dengan bulan Juni 2021 dari 126 ibu hamil usia kurang dari 20 tahun hanya terdapat 53 ibu hamil $(42,06 \%)$ yang melakukan 
kunjungan K1 dan K4 (Kesga, 2021). Survei pendahuluan terhadap 4 bidan di Puskesmas, Puskesmas Pembantu dan Puskesmas Kecamatan Kepahiang menunjukkan bahwa perilaku ibu hamil belum sepenuhnya menjalankan protokol yang telah di buat pemerintah pusat.

Pertama, hal yang sangat menentukan keberhasilan pencapaian tujuan dari implementasi kebijakan publik yaitu komunikasi. Implementasi yang efektif akan terlaksana, jika para pembuat keputusan mengetahui mengenai apa yang akan mereka kerjakan. Kedua, yang mempengaruhi implementasi kebijakan yaitu sumber daya, walaupun isi kebijakan sudah dikomunikasikan secara jelas dan konsistensi, tetapi apabila implementor kekurangan sumber daya untuk melaksanakan, implementasi tidak akan berjalan efektif. Ketiga, disposisi adalah para pelaksana mempunyai sikap positif kecenderungan atau adanya dukungan terhadap implementasi kebijakan maka terdapat kemungkinan yang besar implementasi kebijakan akan terlaksana sesuai dengan keputusan awal. Keempat, untuk menjalankan suatu kebijakan tertentu, maka struktur birokrasi diciptakan. Pengaruh yang signifikan terhadap implementasi kebijakan terhadap mengimplementasikan kebijakan itu sendiri. Adanya prosedur operasi yang standar (Standard Operating Procedures) atau SOP merupakan salah satu aspek struktur penting dari setiap organisasi. Dengan teori ini kita dapat mengetahui bagaimana tenaga kesehatan dalam memberi pelayanan kesehatan terutama pada pelayanan antenatal care yang berkualitas di masa pandemi COVID-19.

Nugroho et al., (2020) penelitiannya yang menunjukkan Implementasi Kebijakan Dinas Kesehatan Dalam Penanganan Gizi Buruk pada Balita di Kabupaten Enrekang bahwa implementasi kebijakan yang dilakukan dinas kesehatan dalam penanganan gizi buruk pada balita di Kabupaten Enrekang, aspek komunikasi sudah berjalan karena terlebih dahulu melakukan sosialisasi, sumber daya yang dimiliki sudah mencukupi sehingga memudahkan, disposisi penanganan tersebut dilakukan dalam bentuk pemberian vitamin, dan struktur birokrasi anak dan remaja putri yang berkerja sama dengan pihak puskesmas dan pihak rumah sakit, adapun yang menjadi faktor pendukung dan penghambat sebagai penggerak pemikir, ataupun perencana untuk mencapai suatu tujuan organisasi dan kurang pemberian vitamin dan suplemen. Selanjutnya Roring et al., (2021) Implementasi Kebijakan Pemerintah dalam Penanganan Virus Corona (COVID 19) di Desa Ongkaw 1 Kecamatan Sinonsayang Kabupaten Minahasa Selatan menggunakan model implementasi Edward III, hasil penelitiannya menunjukkan komunikasi antara lembaga terkait serta adanya dukungan sumberdaya yang diberikan oleh pemerintah pusat, daerah maupun partisipasi masyarakat desa.

Dalam penelitian ini membahas mengenai implementasi kebijakan pelayanan antenatal care bagi ibu hamil pada masa pandemi COVID-19 berdasarkan model implementasi Edwar III yaitu melihat bagaimana implementasi kebijakan pelayanan ANC pada ibu hamil dari segi komunikasi, sumberdaya, disposisi dan struktur birokrasi yang dilaksanakan di Kabupaten Kepahiang pada masa pandemi COVID-19.

\section{METODE PENELITIAN}

Penelitian ini menggunakan rancangan deskriptif kualitatif. Dilakukan di 4 Puskesmas dengan jumlah ibu hamil terbanyak di Kabupaten Kepahiang pada bulan Oktober 2021. Teknik penentuan sampel berdasarkan metode purposive sampling.

Informan dalam penelitian ini adalah Kepala Seksi Kesehatan Keluarga Dinas Kesehatan, Kepala Puskesmas, Bidan Koordinator, Ibu hamil, suami atau keluarga ibu hamil di Kabupaten Kepahiang. 
Pengumpulan data dalam penelitian yaitu dilakukan dengan cara indepth interview dimana dilakukan wawancara mendalam dengan mengajukan beberapa pertanyaan kepada informan, observasi dimana dalam hal ini yang dilakukan yakni mengamati keteserdiaan tenaga kesehatan yang memberi pelayanan, fasilitas kesehatan yang digunakan serta prosedur pelayanan antenatal care yang diberikan, dan dokumentasi yaitu meliputi pendokumentasian data rekam medik atau laporan kunjungan ANC, indentitas ibu hamil yang menjadi informan.

\section{HASIL PENELITIAN}

Kelompok yang rentan risiko terinfeksi COVID-19 salah satunya adalah ibu hamil dikarenakan pada masa kehamilan terjadinya perubahan fisiologi mengakibatkan penurunan kekebalan parsial dan menyebabkan dampak yang serius bagi ibu hamil. Pemerintah melalui Kementerian Kesehatan membuat sebuah kebijakan berupa petunjukan parktis layanan kesehatan ibu dan bayi baru lahir selama Pandemi COVID19 nomor B-4 yang di terbitkan 5 April 2020. Penelitian ini dilakukan untuk mengetahui implementasi pelayanan ANC pada ibu hamil di masa pandemi COVID-19 merujuk pada model implemetasi Edwar III, yang menyatakan bahwa variabel penentu keberhasilan implementasi, terdiri dari: komunikasi, sumberdaya, disposisi, struktur birokrasi. Berikut hasil penelitian yang diperoleh:

\section{Komunikasi}

Hasil wawancara yang telah dilakukan oleh beberapa informan yakni Kepala Seksi Kesehatan Dinas Kesehatan Kabupaten Kepahiang, Kepala Puskesmas, Bidan Koordinator, Bidan Desa dan ibu hamil diketahui bahwa sejauh ini proses komunikasi sudah terjalin dengan baik. Dinas Kesehatan menginformasikan SOP dan kebijakan yang berkaitan dengan Meski dimasa pandemic COVID-19 proses ANC tidak berjalan sebagaimana hari - hari biasa, namun pelayanan dan pengawasan terhadap ibu hamil tetap berjalan. Dinas Kesehatan Kabupaten Kepahiang membuat suatu kebijakan tentang pelaksanaan ANC, yakni untuk ANC pertama sekaligus pengambilan buku pemeriksaan KIA harus dilakukan di Puskesmas, hal tersebut dilakukan agar pada ANC pertama ibu bisa langsung diperiksa oleh dokter, serta dapat melakukan pemeriksaan kadar Hemoglobin, HIV, hepatitis serta pemeriksaan laboratorium lainnya. Sementara pelaksanaan ANC selanjutnya diperbolehkan untuk dilakukan di praktik bidan sesuai dengan ketentuan dan protocol kesehatan.

Proses komunikasi lainnya yang dilakukan di masa pandemi COVID-19 ini, bidan desa membuat group ibu hamil di whatshap guna memantau keadaan ibu hamil karena dimasa pandemi COVID-19 kegaiatan ANC dilakukan berjadwal untuk menghindari kerumunan. Melalui grup whatshap tersebut ibu hamil bisa melakukan konsultasi kepada bidan desa. Selanjutnya keluhan yang dirasakan para ibu hamil akan disampaikan kepada bidan koordinator, selanjutnya akan dibahas pada lokmin maupun staf meeting. Data - data yang telah terjaring yang berisi tentang keadaan ibu hamil khususnya ibu hamil dengan resiko tinggi seperti hamil usia kurang dari 20 tahun akan di laporkan setiap bulan ke Bidang Kesehatan Keluarga Dinas Kesehatan Kabupaten Kepahiang guna menjadai landasan untuk membuat kebijakan atau SOP kedepan nanti.

Kendala komunikasi yang dihadapi diantaranya bagi ibu hamil yang tinggal di daerah yang jauh dari fasilitas kesehatan seperti di kebun, untuk itu petugas kesehatan yakni bidan desa dan kader harus mendatangi ibu tersebut, dan pada saat pemeriksaan kesehatan (ANC) masih ada ibu hamil yang tidak mengenakan masker, untuk itu bagi 
ibu hamil yang dalam kondisi resiko tinggi ataupun yang rumahnya relatif jauh dari Faskes, tenaga kesehatan memeberikan masker.

\section{Sumber Daya}

Hasil wawancara untuk sumber daya manusia ketersediaannya sudah mencukupi, anggaran pelayanan ANC diperoleh dari dari Bantuan Operasional Kesehatan (BOK), Jamkesda, dan Jampersal, untuk fasilitas masker, handscoon, hand sainitazer, tempat cuci tangan telah tersedia, bagi ibu hamil dengan resiko jika saat melakukan pemeriksaan ANC tidak memakai masker pihak Puskesmas akan memberikan masker, informasi dan kewenangan diberikan sesuai dengan tugas dan fungsi serta keadaan dilapangan.

\section{Disposisi}

Hasil wawancara tentang disposisi didapatkan hasil yaitu dalam memudahkan proses pelayanan dan pegawasan Dinas Kesehatan dan Kepala Puskesmas membentuk Tim Mutu Kesehatan yang akan mengawasi proses pelayanan, sedangkan untu dilapangan bidan koordinator menunjuk bidan desa dan kader yang diberi tugas untuk mendampingi ibu hamil khususnya ibu hamil dengan resiko tinggi seperti ibu hamil kurang dari 20 tahun. Ibu hamil yang berusia kurang dari 20 tahun termasuk kedalam kelompok resiko tinggi, dikarenakan usia yang masih muda, ibu hamil untuk perlu mendapatkan pendampingan baik dari pihak keluarga maupun tenaga kesehatan seperti kader, untuk mencegah hal yang tidak diinginkan.

\section{Struktur Birokrasi}

Hasil wawancara tentang birokrasi pembagian tugas dan kewenangan telah dilakukan sesuai tugas dan fungsi masing-masing implementor. Dinas Kesehatan melalui seksi Kesehatan keluarga berfungsi sebagai pembuat kebijakan/SOP, Puskesmas selaku pelaksana pelayanan sekaligus pembuat SOP yang disesuaikan dengan keadaan dilapangan, bidan koordinator berwenang atas bidan desa dan kader, bidan desa bertugas memberi pelayanan kepada ibu hamil yang tinggal di desa dibantu dengan kader posyandu. Tiap lini diberi tanggung jawab untuk melaporkan hasil penjaringam khususnya mengenai keadaan ibu hamil di masa pandemic COVID-19, dikarena selama pandemi COVID-19 khsusunya saat zona Kabupaten Kepahiang berada pada zona merah kegiatan posyandu, kelas ibu hamil di tiadakan untuk sementara.

\section{PEMBAHASAN}

\section{Implementasi Kebijakan Pelayanan Antenatal Care bagi Ibu Hamil pada Masa Pandemi COVID-19 Berdasarkan Faktor Komunikasi}

Secara garis besar proses komunikasi telah dilakukan dengan baik. Perubahan jadwal pelayanan ANC di masa pandemi COVID-19 dan tata laksana pelayanan telah diatur melalui SOP baik yang dibuat oleh Dinas Kesehatan Kabupaten Kepahiang maupun pihak puskesmas, hal tersebut diinformasikan kepada masyarakat melalui bidan koordinator diteruskan kepada bidan desa serta kader Posyandu untuk selanjutnya disampaikan kepada masyarakat khususnya ibu hamil.

Untuk memudahkan proses pengawasan kepada ibu hamil di masa pandemi COVID dibuatlah sistem penjaringan melalui grup whatsapp, disana para ibu hamil bisa melakukan konsultasi dan menyampaikan keluhan yang ia rasakan selama proses 
kehamilan dan bidan akan memberi arahan, jika masalah atau keluhan yang dirasakan belum teratasi, maka ibu hamil dianjurkan untuk mendatangi fasilitas kesehatan dengan mengikuti protokol kesehatan. Dari uraian tersebut terlihat proses komunikasi telah berjalan dengan baik sehingga implementasi pelayananan ANC di masa pandemic dapat berjalan dengan lancar meski masih terdapat beberapa kendala (World Health Organization, 2019).

\section{Implementasi Kebijakan Pelayanan Antenatal Care bagi Ibu Hamil pada Masa Pandemi COVID-19 Berdasarkan Faktor Sumber Daya}

Keberadaan sumber daya sangat mendukung keberhasilan implementasi sebuah kebijakan tanpa adanya sumberdaya yang menunjang seperti sumberdaya manusia, fasilitas, dan anggaran, informasi yang cukup serta kewenangan implementasi yang dibuat sulit untuk mencapai sasaran.

Untuk keberadaan sumberdaya baik sumber daya manusia, fasilitas, anggaran dana untuk implementasi kebijakan pelayanan ANC pada ibu hamil pada masa pandemi COVID-19 di Kabupaten Kepahiang secara umum telah terpenuhi, namun kendala yang dihadapi adalah masih ditemukan kurangnya disiplin baik masyarakat dalam pelaksanaan protokol kesehatan seperti tidak memakai masker saat datang ke fasilitas kesehatan, sementara ketidakdisiplinan dari petugas yakni pada saat tertentu petugas yang semestinya terjadwal untuk memberikan pelayanan kepada masyarakat karena keadaan tertentu berhalangan hadir, sehingga tanggung jawab tersebut dilakukan oleh petugas lainnya.

\section{Implementasi Kebijakan Pelayanan Antenatal Care bagi Ibu Hamil pada Masa Pandemi COVID-19 Berdasarkan Faktor Disposisi}

Disposisi disini diartikan sebagai perilaku yang menyangkut karakteristik pelaksana kebijakan dalam hal ini yakni Dinas Kesehatan, Kepala Puskesmas, dan bidan koordinator. Demi kelancaran proses pelayanan, tenaga pelaksana pelayanan haruslah dipilih berdasarkan keahlian, dan untuk mengontrol pelaksaan tugas perlu dilakukan pengawasan. Dalam hal ini proses pengawasan dilakukan oleh tim mutu dari pihak puskesmas yang telah dibentuk, dan pengawasan sekaligus evaluasi yang dilakukan oleh dinas kesehatan dalam bentuk Bimbingan teknis Pelayanan Obstetri Neonatal Emergensi Dasar (PONED).

Selain adanya struktur birokrasi dan pembagian kewenangan, pemberian insentif khususnya pada petugas dilapangan terlebih yang belum berstatus pegawai perlu dilakukan, guna memacu semangat kerja (Fauzi, 2020).

\section{Implementasi Kebijakan Pelayanan Antenatal Care bagi Ibu Hamil pada Masa Pandemi COVID-19 Berdasarkan Faktor Struktur Birokrasi}

Struktur birokrasi tentunya sangat diperlukan untuk mengatur sumber daya atau pelaksana, yang bertujuan agar dapat melaksanakan suatu kegiatan dengan kondusif dan terkoordinasi dengan baik. Diperlukan struktur birokrasi yang kuat dan dapat mengatur kerjasama orang-orang atau sumber daya didalamnya secara efektif dalam pengelolaan kebijakan.

Dimasa pandemi Pemeriksaan kehamilan tentu akan mengalami kendala, akan tetapi dapat dilakukan selama ibu hamil dan petugas kesehatan menerapkan protokol kesehatan COVID-19 selama asuhan pemeriksaan kehamilan (Pitale, 2020). Oleh 
karena itu, di masa pandemi ini, ibu hamil perlu mengetahui cara melindungi diri dengan benar.

Pada implementasi kebijakan pelayanan ANC pada masa pandemi COVID-19 di Kabupaten Kepahiang tidak ada tim khusus namun pelaksanaan tugas dan tanggung jawab harus dilaksanakan berdasarkan SOP yang dibuat oleh dinas kesehatan maupun masing - masing Puskesmas yang merujuk pada petunjukan parktis layanan kesehatan ibu dan bayi baru lahir selama Pandemi COVID-19 nomor B-4 yang di terbitkan 5 April 2020. Struktur birokrasi yang digunakan merupakan struktur yang telah ada di Dinas Kesehatan maupun Puskesmas dan pembagian wewenang dilakukan berdasarkan tugas dan fungsi tenaga kesehatan sesuai dengan bidang masing-masing. Selain itu demi kelancaran proses pelayanan ANC dibutuhkan kerjasama yang baik antar unit pelaksanan pelayanan. Pelayanan kesehatan dasar dilakukan oleh Puskesmas yang meliputi bidan desa dan kader Posyandu, sementara jika ditemukan kegawatdaruratan ibu hamil dirujuk ke fasilitas kesehatan yang lebih lengkap yakni rumah sakit atau dokter spesialis (Cahyanti, 2021).

Dari uraian hasil penelitian di atas, hasil penelitian sejalan dengan penelitian terdahulu yang dilakukan oleh Nugroho et al., (2020) penelitiannya yang mengenai Implementasi Kebijakan Dinas Kesehatan Dalam Penanganan Gizi Buruk pada Balita di Kabupaten Enrekang, menunjukkan bahwa implementasi kebijakan yang dilakukan dinas kesehatan dalam penanganan gizi buruk pada balita di Kabupaten Enrekang, aspek komunikasi sudah berjalan karena terlebih dahulu melakukan sosialisasi, sumber daya yang dimiliki sudah mencukupi sehingga memudahkan, disposisi penanganan tersebut dilakukan dalam bentuk pemberian vitamin, dan struktur birokrasi terhadap anak dan remaja putri yang berkerja sama dengan pihak puskesmas dan pihak rumah sakit di Kabupaten Engkrang, hal tersebut menjadi faktor pendukung dan penghambat sebagai penggerak pemikir dan ataupun perencana dalam mencapai suatu tujuan organisasi dan kurang pemberian vitamin dan suplemen.

Selanjutnya Roring et al., (2021) Implementasi Kebijakan Pemerintah dalam Penanganan Virus Corona (COVID-19) di Desa Ongkaw 1 Kecamatan Sinonsayang Kabupaten Minahasa Selatan menggunakan model implementasi Edward III, hasil penelitiannya menunjukkan komunikasi antara lembaga terkait serta adanya dukungan sumberdaya yang diberikan oleh pemerintah pusat, daerah maupun partisipasi masyarakat desa. Dari hasil penelitian disimpulkan bahwa Implementasi kebijakan pelayanan ANC ibu hamil pada masa pandemic COVID-19 dari model implementasi Edward III meliputi komunikasi, dan sumber daya, secara umun telah berjalan dengan baik dan pelaksanaan ANC tetap berjalan dengan mengukit SOP protokol kesehatan.

\section{SIMPULAN}

Secara garis besar implementasi kebijakan pelayanan ante natal care bagi ibu hamil pada masa pandemi COVID-19 di Kabupaten Kepahiang berjalan dengan baik. Dari segi sumber daya untuk tenaga kesehatan sudah memiliki standarisasi dalam pemberian pelayanan serta standar pendidikan yang baik, fasilitas kesehatan sudah memadai dan sudah adanya bantuan dana dari pemerintah, selain dana kesehatan untuk ibu hamil, juga adanya dana bantuan lainnya seperti pemberian masker dan handsanitizer untuk ibu hamil saat akan melakukan pemeriksaan kehamilan terutama dimasa pandemi COVID-19. Dari segi disposisi sudah adanya pendampingan oleh tenaga kesehatan pada ibu hamil dalam memberikan pelayanan ANC, terutama bagi ibu hamil yang memiliki masalah jarak tempuh yang jauh untuk menuju fasilitas kesehatan. 
Struktur organisasi secara umun telah berjalan dengan baik sehingga pelaksanaan ANC tetap berjalan dengan mengikuti SOP protokol kesehatan.

\section{SARAN}

Perlu ditingkatkannya upaya promosi kesehatan khususnya tentang pentingnya pemeriksaan kehamilan atau antenatal care khususnya pada ibu hamil usia kurang dari 20 tahun yang termasuk kedalam kelompok kehamilan dengan resiko.

\section{DAFTAR PUSTAKA}

Aritonang, J., Nugraeny, L., Sumiatik, \& Siregar, R. N. (2020). Peningkatan Pemahaman Kesehatan pada Ibu hamil dalam Upaya Pencegahan COVID-19. Jurnal SOLMA, 9(2), 261-269. https://doi.org/10.22236/solma.v9i2.5522

Cahyanti, L. D. (2021). Faktor - Faktor yang berhubungan dengan kunjungan Antenatal Care (ANC) Ibu Hamil di Era Pandemi COVID-19 di Wilayah Kerja Puskesmas Jember Kidul Kabupaten Jember. Universitas Islam Negeri Maulana Malik Ibrahim Malang. http://etheses.uin-malang.ac.id/29965/

Fauzi, A. (2020). Implementasi Pembatasan Sosial Berskala Besar, Sebuah Kebijakan Publik dalam Penanganan Pandemi COVID-19. Jurnal Ilmu Administrasi Negara, 16.1, 174-178. https://jiana.ejournal.unri.ac.id/index.php/JIANA/article/view/7946

Gugus Tugas Percepatan Penanganan COVID-19. (2020). Protokol Petunjuk Praktis Layanan Kesehatan Ibu dan Bayi Baru Lahir Selama Pandemi COVID-19. Protokol Gugus Tugas Percepatan Penanganan COVID-19 Ri, 4(April), 1-11. https://COVID19.go.id/p/protokol/protokol-b-4-petunjuk-praktis-layanankesehatan-ibu-dan-bbl-pada-masa-pandemi-COVID-19

Hasugian, L. E., Zuska, F., Sitorus, M. E. J., Dachi, R. A., Brahmana, N. B., \& Sinaga, L. V. (2021). Analisis Pelaksanaan Pelayanan ANC pada Masa Pandemi COVID19 di Wilayah Kerja Puskesmas Parlilitan Kecamatan Parlilitan Kabupaten Humbang Hasundutan Tahun 2021. Journal of Healthcare Technology and Medicine, $7(2)$, 1236-1250. https://jurnal.uui.ac.id/index.php/JHTM/article/download/1666/868

Kementerian Kesehatan RI. (2020). Pedoman bagi Ibu Hamil, Ibu Nifas, dan Bayi Baru Lahir Selama Social Distancing. Jakarta: Kemenkes RI

Kesga. (2021). Laporan Capaian Kinerja Agustus 2021. https://kesga.kemkes.go.id/

Nugroho, E. E., Mahsyar, A., \& Usman, J. (2020). Implementasi Kebijakan Dinas Kesehatan Dalam Penanganan Gizi Buruk Pada Balita Di Kabupaten Enrekang. Universitas Muhammadiyah Makassar, 1(2), 700-714. https://journal.unismuh.ac.id/index.php/kimap/article/viewFile/3709/3001

Pitale, D. L. (2020). Antenatal Care During the COVID-19 Pandemic. International Journal of Reproduction, Contraception, Obstetrics and Gynecology, 9(10), 4052. 10.18203/2320-1770.ijrcog20204286

Roring, A. D., Mantiri, M., \& Lapian, M. T. (2021). Implementasi Kebijakan Pemerintah dalam Penanganan Virus Corona (COVID-19) di Desa Ongkaw 1 Kecamatan Sinonsayang Kabupaten Minahasa Selatan. Jurnal Governance Sadat, 1(1), 1-10. https://ejournal.unsrat.ac.id/index.php/governance/article/view/34838/0 
Unicef. (2019). Impact (Integrated Management of Pregnancy and Childbirth), Managing Complications in Pregnancy and Childbirth: Aguide for Midwives and Dovtor, Department of Reproductive Health and Research

World Heatlh Organization. (2019). Who Recommendations on Antenatal Care for a Positive Pregnancy Experience. Switzerland : Who, 12-83 